\title{
Internalization of Pancasila Economics Values in Elementary School Students
}

Sri Umi Mintarti Widjaja ${ }^{1}$

${ }^{1}$ Faculty of Economics, Universitas Negeri Malang, Indonesia

\section{Article Info}

Article history:

Received: 09 December 2020;

Accepted: 26 March 2021;

Published: 28 March 2020.

Keywords:

Early Childhood; Elementary School; Pancasila Economics Values.

\begin{abstract}
This study aims to find out how to be wise in instilling Pancasila-based economic values in elementary school students and implementing their economic learning. The qualitative descriptive method is used in this research. The research participants were teachers at SD Negeri Kampungdalem I, SD Negeri Bungur I, and SD Negeri Ngentrong, who teach in grades 1-5. Data collection was carried out by observation, documentation, and in-depth interviews. Furthermore, data analysis reduces data, displays or displays data, and finally. The data triangulation method was used to test the validity of the data before dis. The results of the study as a whole show that elementary school teachers make efforts in applying the economic value of Pancasila to students. These efforts have a positive impact in shaping students' character based on the economic values of Pancasila. Even so, the application of Pancasila economic values for early childhood in elementary schools needs improvement. Schools also provide more support and attention to these efforts.
\end{abstract}

\begin{abstract}
Abstrak
Penelitian ini bertujuan untuk mengetahui bagaimana upaya guru dalam menanamkan nilai ekonomi berbasis pancasila pada siswa sekolah dasar dan pelaksanaan pembelajaran ekonomi mereka. Metode deskriptif kualitatif digunakan dalam penelitian ini. Partisipan penelitian adalah para guru di SD Negeri Kampungdalem I, SD Negeri Bungur I, dan SD Negeri Ngentrong, yang mengajar di kelas 1-5. Pengumpulan data dilakukan dengan observasi, dokumentasi, dan wawancara mendalam. Selanjutnya analisis data mereduksi data, menyampaikan atau menampilkan data dan kesimpulan. Metode triangulasi data digunakan untuk menguji keabsahan data sebelum disimpulkan. Hasil penelitian secara keseluruhan menunjukkan bahwa para guru sekolah dasar melakukan beberapa upaya dalam menerapkan nilai ekonomi pancasila pada siswa. Upaya tersebut berdampak positif dalam membentuk karakter peserta didik berlandaskan nilai-nilai ekonomi Pancasila. Meskipun demikian, penerapan nilai-nilai ekonomi Pancasila untuk anak usia dini di sekolah dasar perlu ditingkatkan. Sekolah juga perlu memberikan dukungan serta perhatian lebih terhadap upaya tersebut.
\end{abstract}

\section{How to Cite:}

Widjaja, S. U. M. (2021). Internalization of Pancasila Economics Values in Elementary School Students. Jurnal Pendidikan Ekonomi \& Bisnis, 9(1), 64-71. https://doi.org/10.21009/JPEB.009.1.7

* Corresponding Author.

sri.umi.fe@um.ac.id. Sri Umi Mintarti Widjaja 


\section{INTRODUCTION}

Early childhood is an essential momentum for child development (Winder \& Corter, 2016; Burger, 2010). All cognitive aspects of children experience rapid growth, so it is called the "golden age" or golden age (Mansur, 2005; Wibowo, 2012). Early childhood is also the most significant period for parents in providing education to children (Siraj, 2004; Wibowo, 2012; Wibowo; 2012). Likewise, the cultivation of fundamental economic values based on Pancasila is beneficial when given at the golden age (Agussalim et al., 2021). At this age, children will easily absorb the material or knowledge given and quickly understand the material they receive. The provision of economic values based on Pancasila is critical to be given since early childhood. This strategy is because almost all of the economics lessons given at the junior and senior high school levels are economies that are oriented towards liberalism or capitalism.

Economic education is vital to be given from early childhood because the knowledge obtained from economic education is instrumental in adult life, especially economic education in money management (Koeller, 1981; Sunanik, 2016; Hanushek \& Woessmann, 2020). A survey by the Financial Service Authority (FSA, 2002) found that 6 out of 10 elementary schools and 9 out of 10 junior high schools in the UK (UK) consider personal finance education to be significant (Bernadene 2009). To improve the ability to understand population finances, AICPA in America and SAICA in South Africa implement the 360 Degrees of Financial Literacy Program" which applies a comprehensive approach to financial education for all ages ranging from children to retirees (Bernadene, 2009; Lewis \& Scott, 2000; Lucey, 2019; Rahmatullah, 2018).

Astuti's research (2013) and Bhudianto (2012) found two economic actions, namely rational economic actions, namely economic actions tailored to their needs and abilities. Meanwhile, irrational economic actions are economic actions that are not by their needs and abilities. The economic motive is the human impulse to take economic action; it can come from within himself or come from environmental influences. Several factors give rise to economic motives, namely: (1) motive for fulfilling needs, (2) motive for gaining power, (3) motive for gaining appreciation, (4) motive for helping fellow human beings, (5) motive for obtaining benefits (Astuti, 2013). Class teachers are always expected to insert these economic motives in a comprehensive frame, meaning that not each motive stands alone in the given subject. The delivery of this economic motive is, of course, adjusted to the development and level of thinking of the children. So, in practice, the cultivation of Pancasila values related to economic motives should not burden children's minds.

The Indonesian economy is based on clause 33 of the UUD 1945, which contains three economic principles in Indonesia, namely: (1) the economy is structured as a joint venture based on the principle of kinship; (2) production branches which are essential to the state and which affect the livelihood of the general population shall be controlled by the state; and (3) the land, water and all the wealth contained therein shall be controlled by the state and used for the greatest prosperity of the people. Clause 33 of the UUD 1945 shows that every citizen has the same opportunity to achieve a prosperous life and has the same rights in running the economy. This basic concept of the Indonesian economy must be introduced to all Indonesian people of all ages. It is just that the method of introduction is adjusted to the level of understanding, age level, and level of human development. In the context of national economic education, this basic concept of the Indonesian economy must be integrated into existing subjects at each level of education so that in the future, they have economic knowledge that is by the philosophy of our country, Pancasila (Mubiyarto \& Budiyono, 1980, 1987; Mubyarto, 2004; Dumairy \& Nugroho, Tarli, 2014).

The internalization of economic principles based on Pancasila includes the points in each of the precepts, 45 points. This planting must be done from early childhood, both in the family and at school, in this case, the elementary school (SD). According to Robert (2011), Hanushek and Woessmann (2020), knowledge obtained from an early age will remain in their minds until old age. Therefore, children's economic education is essential to do; just as the reading ability is vital, economic understanding is equally vital. The teaching of economic concepts through children's stories or regional stories is very suitable for early childhood or children at the elementary school level. It can be done using simulations because by playing a game, and each student has a role, their 
learning will be easy to understand and understand.

As stated by Gagne (1985), one that can be relied upon in changing attitudes is the human model. In this learning, learning results from imitating the behavior of the person who is being used as a model or, more precisely, imitating his choice of action. A school where children socialize with many people from various environments. They can relate to teachers, with peers, or with people around the school. By socializing from various environments, students will have more broad insights, especially in applying the values of Pancasila in their lives. The provision of knowledge of economic values based on Pancasila, which is given from an early age, will be easily absorbed, understood, understood, and imprinted in their minds until adulthood.

Based on Law No. 20 of 2003, it is stated that early childhood education is a coaching effort aimed at children from birth to 6 years of age which is carried out by providing educational stimuli to assist physical and spiritual growth and development so that children have readiness. In entering further education. Early childhood is children who are in the process of growth and development (fine and gross motor coordination), intelligence (thinking power, creativity, emotional intelligence, and spiritual intelligence), social-emotional (attitudes and behavior and religion), language, and communication precisely according to the level of growth and development of the child.

According to Mansur (2005), early childhood is a group of children who are in a unique process of growth and development. They have a specific growth and development pattern according to the rate of growth and development. Based on the uniqueness of their growth and development, early childhood is divided into three stages, namely infancy to 12 months, toddlers aged 1-3 years, preschool age 3-6 years, and early grades of SD 6-8 years. (Mansur 2005: 88). According to Aisyah et al. (2010), characteristics of early childhood, among others; a) has excellent curiosity, b) is a unique person, c) likes to fantasize and imagine, d) has the most potential for learning, e) shows an egocentric attitude, f) has a short concentration power range, g) as part of social beings.

According to Sa'dun Akbar and Hadi Sriwiyana (2010), Social Studies education is a subject that children must take at the primary and secondary school levels. This argument is as stated by Law Number 20 of 2003 concerning the National Education System in article 37, which states that the primary and secondary education curriculum must contain social science. Social Sciences (IPS) examines a set of events, facts, concepts, and generalizations related to social issues. The purpose of social studies education taught in elementary schools is to educate and equip students with basic self-development abilities according to their respective talents, interests, abilities, and environment. Also, elementary students are provided with basic knowledge to continue their education to a higher level (middle level). Therefore, according to Sidiharjo (1997), considering the level of intelligence, mental maturity of students, the educational materials are simplified, selected, adapted, and modified for institutional purposes. Figure 1 below is a chart of the scope of social studies learning at the elementary level, as contained in the subject of elementary school/madrasah ibtidaiyah (Kemendikbud, 2016). 


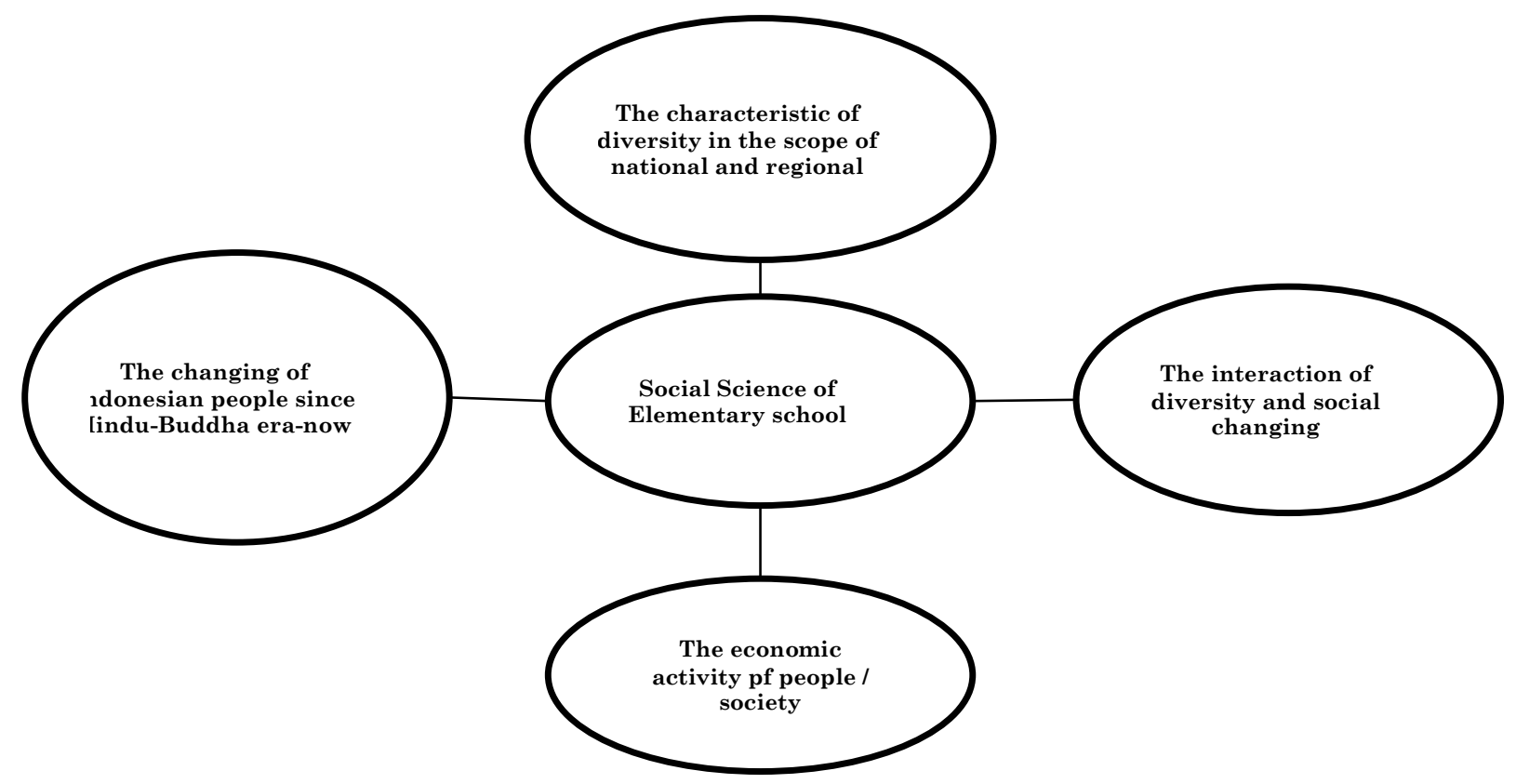

Figure 1. The scope of SD social studies learning

(Source: Kemendikbud, 2016))

Based on the studies of previous scholars (Sidiharjo, 1997; Siraj, 2004; Hadi Sriwiyana, 2010; Agussalim et al., 2021) that economic education should ideally begin when children enter school. Therefore, primary education teachers (SD teachers) are expected to be able to assist students in learning basic economic concepts properly. If since elementary school age the child has been able to master economic concepts, then this will help them understand the financial world that exists in the environment around where they live. Based on these assumptions, it is hoped that the cultivation of economic values based on Pancasila can become a filter for Indonesian children in carrying out economic activities when they grow up. They will examine which economic activities are by the country's philosophy, which is by the Indonesian people's spirit. The concept of a just cooperation economy can be implemented later by them in doing the economy.

This study provides insight into significant contributions; first, in the literature related to Pancasila-based economic education at an early age. If the study of Agussalim et al. (2021) focuses on secondary schools, so this study focuses on elementary schools that have not been studied by scholars. Second, provide insight into how vital the internalization of Pancasila-based economic education in schools is to be carried out effectively. Third, provide input regarding the importance of schools' role in supporting the process of internalizing Pancasila-based economic education at the elementary school level.

\section{METHOD}

This study used a qualitative descriptive design. This study describes a phenomenon in children's learning in elementary schools, especially in the internalization of economic values based on Pancasila. The research locations were SD Negeri Kampungdalem I, SD Negeri Bungur I, and SD Negeri Ngentrong. The subjects of this study were elementary school teachers who taught in grade one to grade five. For grade one, grade two, and grade three, although there are no economic lessons (IPS), interviews are conducted, but only limited to how the teachers instill the values of Pancasila in every lesson that is carried out. Meanwhile, for class IV and V teachers, interviews were conducted to instill Pancasila-based economic principles in learning.

Research instruments in this study were observation sheets, documentation, and in-depth interviews. The researcher conducted in-depth interviews before and during the study. Preobservations aim to determine how teachers understand economic values, which need to be given to 
elementary school students. In comparison, observations made during classroom observations aim to determine how economic values are integrated into each teacher's subject matter. In-depth interviews were conducted with teachers and students. The expected results from interviews conducted with teachers are to obtain data about the methods that have been used by teachers in instilling economic values based on Pancasila to elementary school students.

Meanwhile, the researcher applied interviews to determine whether the students understood what economic learning was based on Pancasila. Documentation to obtain data about the number of students in each class, class teachers, and subject teachers. Besides, documentation also to records the facilities and infrastructure owned by the school that can support the implementation of these activities.

Data analysis in this study is using an interactive model revealed by Miles, Huberman, \& Saldaña, J. (2014): (1) Data reduction. This activity is to sort out the data obtained from observations and interviews. Researchers removed inconsistent data from existing data sets. Furthermore, the researcher uses the appropriate data for further analysis, (2) The selected data are presented in the form of a description based on the information obtained, (3) Make conclusions on the findings of the data that have been described, (4) In order for the results of this study to be perfect, the researcher checks the validity of the data, by triangulating sources (see figure 2).

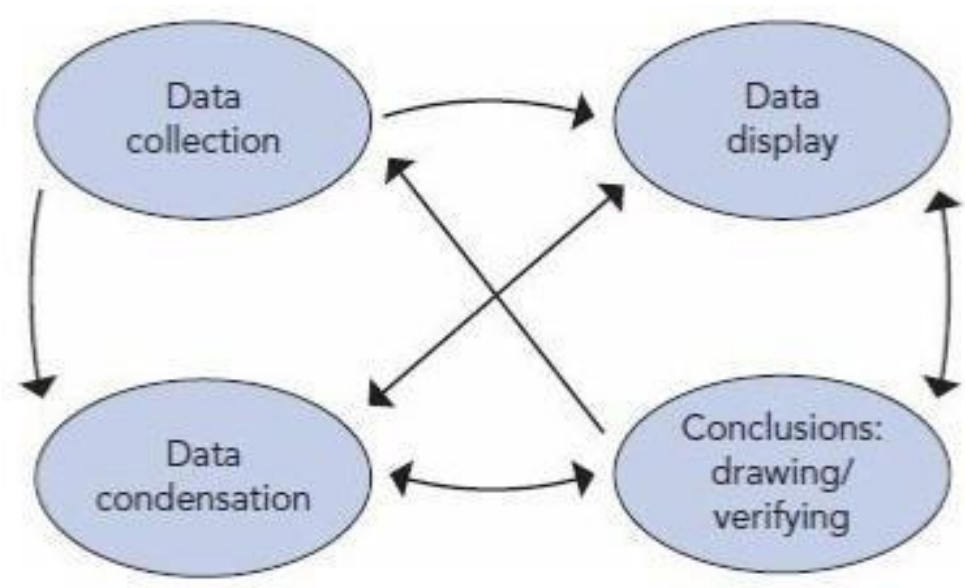

Figure 2. Interactive Model of Data Analysis

Source: Adapted from Miles, Huberman, \& Saldaña (2014)

\section{RESULTS AND DISCUSSION}

This research was conducted to determine teachers' efforts to instill economic values based on Pancasila in elementary school students and their implementation in learning, for example, how teachers instill in children to be able to share with their friends if their friends need help. Teachers do so that children like to save, especially from pocket money obtained from their parents or siblings, and various other economic problems.

Based on the focus in this study, the study results indicate that some of the efforts made by teachers in instilling Pancasila-based economic values in elementary school students are first to provide exemplary (real examples) in everyday life. This will have a positive impact on student learning in the classroom; by teaching the principles of Pancasila-based Economics in the Social Studies subject through this example, students can better understand that in learning about money material (Economics material), students also need to learn how to behave. Wise (Pancasila values) in managing the money. This value is by the points in the 2nd precept point 6 and 7, namely upholding human values and fond of doing humanitarian activities, and this is also by the 5th precept point 5, which is like to give help to others so that they can be stand-alone. The results of this study are relevant to several previous studies, such as those conducted by Sidiharjo (1997), Siraj (2004), Dumairy and Nugroho (2014), Hadi Sriwiyana (2010), and Agussalim et al. (2021). 
The second, linking the economic concept being taught with Pancasila values. The results showed that the teachers who had been interviewed by researchers had various variations in linking the material being studied with Pancasila values. Usually, in the process of linking this subject matter, the teachers analyze from the side of the students the content of the material, as well as the surrounding geographical conditions that might be made a connection. By providing this contextual link, the teacher can convince students to learn. This strategy will have a positive impact on our students, they will be accustomed to living by Pancasila, and of course, they will try to see things from the perspective of Pancasila in every decision making, whether in social, economic, or cultural life. Doing good is also by what is in the second precept, point 1 , namely recognizing and treating humans according to dignity as God Almighty's creatures. The results of this study are relevant to several previous studies, such as those conducted by Sidiharjo (1997), Siraj (2004), Hadi Sriwiyana (2010), and Agussalim et al. (2021).

The fourth finding, the teacher, collaborates with the parents of students in instilling Pancasila values. Based on the results of this study, teachers in Tulung Agung district always try to collaborate with parents in instilling the values of Pancasila. Social studies (economics) teachers, for example, try to synchronize what is taught to their students at school with what is in the family environment. Teachers always communicate with parents in this house, with Pancasila, especially precepts 1 , point 2, to develop an attitude of respect and cooperation between religions and followers of different beliefs towards God Almighty. The results of this study are relevant to previous studies, such as those conducted by Hadi Sriwiyana (2010), and Agussalim et al. (2021).

The fifth findings, the teacher, delivers material related to Pancasila-based economic actors. In this context, the teacher provides an example of economic activities as sellers and buyers, often carried out by students, teachers, and their surroundings. Furthermore, the teacher provides examples of economic behavior that should be carried out by economic actors based on the economic values of Pancasila. Submission of samples is adjusted to elementary school-age children's development (Koeller, 1981; Sunanik, 2016; Hanushek \& Woessmann, 2020). This is by Pancasila, especially the 5th principle point $3,4,6$, which is about: maintaining a balance between rights and obligations (point 3), respecting others' rights (item 4), and not using property rights for businesses of nature. Extortion of others (item 6). The results of this study are relevant to previous studies, such as those conducted by Hadi Sriwiyana (2010), and Agussalim et al. (2021).

The researcher also found all material taught in elementary school is done so that the teacher consistently links the points in Pancasila. The goal is that children from an early age understand, and in turn, can apply it in everyday life. Like the use of money, the teacher relates to the 6th and seventh points of the second principle, and the 9th point of the fifth principle, namely upholding human values (item 6), likes to do humanitarian activities (item 7), likes to work hard (item 9). In the material on the market, the teacher tries to relate the material to Pancasila points, namely as a seller or a buyer, must not be arbitrary towards others, and must also be considerate of each other, tepo seliro towards others. This is by the second precepts of items 4 and 5 , namely developing an attitude of mutual tolerance and tepo selira (item 4) and developing an arbitrary attitude towards others (item 5). Likewise, in the material of cooperation with foreign countries, the teacher tries to link with the second principle of point 10, namely developing an attitude of respect and respect and cooperation with other nations.

\section{CONCLUSIONS AND SUGGESTION}

Based on the results of the study, it is known that the teacher's efforts to internalization economic values based on Pancasila have been carried out since grade 1 . However, at this level, no social studies are learning. For example, they were using water because using water as needed will impact the economy, namely saving. In the material on the types of work and money, the teacher tries to make students realize that money is earned from work, so it must be used effectively and as effectively as possible. In short, humans must be willing to work hard to earn income (money). After earning income, it must be used effectively and efficiently. Furthermore, students are encouraged 
to save because savings can be used for urgent needs, for example helping friends who need it.

Based on the research results, it is known that the teachers teach natural resources (SDA) material by providing pictures that reflect how to use natural resources properly. Every person has the right to use natural resources to obtain life's welfare, with due observance of existing regulations. This is by the principles of cooperatives as the practice of Pancasila, especially Article 33 of the 45 Constitution, which adheres to the principles of kinship and cooperation. As for the material related to cooperation with abroad, it is conveyed to students because Indonesia as a country cannot possibly fulfill its own domestic needs if it does not cooperate with other countries. Cooperation must be carried out with due regard to shared interests, not individuals' or groups' interests.

Based on the results of the study, the researchers provided recommendations. First, schools can increase activities to instill Pancasila-based economic values by linking each learning material with Pancasila's points. Second, teachers are expected to increase efforts to embed Pancasila points in social studies learning materials, especially those related to economics. So that later children can apply the points of Pancasila when they become one of the economic actors in their daily life. Third, the government should encourage teachers to apply the points of Pancasila in learning by holding competitions so that there is an appreciation for teachers who have achievements in instilling Pancasila values in learning.

Limitations of this study were only conducted in one public school. Further researchers need to involve private schools so that the research results can provide valuable insights into the internalization of Pancasila economic values in social studies learning in elementary school public and private. The results of this study also need to be followed up with a quantitative research model so that a model of the internalization of the economic values of Pancasila can be found in all primary schools, both public and private, in Indonesia.

\section{REFERENCES}

Adams, E. C. (2019). Economics and the civic mission of social studies education: Two critiques of neoclassicism. Citizenship, Social and Economics Education, 204717341984191. Doi: $10.1177 / 2047173419841915$.

Agussalim.,Widjaja, S. U. M., Haryono, A., \& Wahyono, H. (2021). Pancasila Economic Character Literacy Program for High School Students. International Journal of Instruction, 14(1), 235-

252. https://doi.org/10.29333/iji.2021.14114a

Agussalim. (2019). Ekonomi Pancasila dan Implikasinya dalam Pembelajaran Ekonomi. Jurnal PenKoMi: Kajian Pendidikan dan Ekonomi STKIP Bima, 2(1), 16-30 https://doi.org/10.33627/pk.v2i1.150

Aisyah, Siti (2010). Perkembangan dan Konsep Dasar Pengembangan Anak Usia Dini. Jakarta: Universitas Terbuka.

BSNP. (2006). Permendiknas RI No. 22 Tahun 2006 tentang Standar Isi untuk Satuan Pendidikan Dasar dan Menengah. Jakarta: Depdiknas

Burger, K. (2010). How does early childhood care and education affect cognitive development? An international review of the effects of early interventions for children from different social backgrounds. Early Childhood Research Quarterly, 25(2), 140-165. doi:10.1016/j.ecresq.2009.11.001.

Bhudianto, W. Dkk. (2012). Sistem ekonomi kerakyatan dalam globalisasi perekonomian. Transformasi, $\quad$ Vol.XIV(No

http://ejurnal.unisri.ac.id/index.php/Transformasi/article/view/45/18

Dumairy \& Nugroho, Tarli. (2014). Ekonomi Pancasila: Warisan Pemikiran Mubyarto. Gadjah Mada University. Yogyakarta : Anggota IKAPI

Departemen Pendidikan Nasional. (2003). Undang-Undang Nomor 20 Tahun 2003, Tentang Sistem 
Pendidikan Nasional. Jakarta: Depdiknas.

Gagne,E.D.(1985). The Cognitive Psychology of School Learning. Toronto: Little Brown Company.

Hanushek, E. A., \& Woessmann, L. (2020). The economic impacts of learning losses. OECD.

Kementrian Pendidikan dan Kebudayaan (2016). Permendikbud Tahun 2016 Nomor 024 Lampiran 10, Tentang KI dan KD KK 2013 SD/MI IPS. Jakarta: Kementrian pendidikan dan Kebudayaan.

Kementrian Pendidikan Nasional. (2009). Permendiknas Nomor 58 Tahun 2009 Tentang Standar Pendidikan Anak Usia Dini. Jakarta: Kementrian Pendidikan Nasional

Koeller, S. (1981). Economics Education Applied to Early Childhood. Childhood Education, 57(5), 293-296. doi:10.1080/00094056.1981.10520471

Lewis, A., \& Scott, A. J. (2000). The Economic Awareness, Knowledge and Pocket Money Practices of a Sample of UK Adolescents: A Study of Economic Socialisation and Economic Psychology. Citizenship, Social and Economics Education, 4, 34-46. doi: 10.2304/csee.2000.4.1.34

Lucey, T. A. (2019). Examining a measure of spiritual capital: Perceptions of business and education majors. Citizenship, Social and Economics Education, 18, 3-15. doi: 10.1177/2047173418823543

Mansur. (2005). Pendidikan Anak Usia Dini Dalam Islam. Yogyakarta: Pustaka Pelajar.

Miles, M.B., Huberman, A.M., \& Saldaña, J. (2014). Qualitative data analysis: A methods sourcebook (3rd edition). New York: SAGE Publications, Inc

Mubiyarto \& Budiyono. (1980). Ilmu Ekonomi, Ilmu Sosial Dan Keadilan. Yogyakarta: UGM PRES.

Mubiyarto \& Budiyono. (1987). Ekonomi Pancasila. Yogyakarta: BPFE- Yokyakarta.

Mubyarto. (2004). Pendidikan Ekonomi Kita. Yogyakarta: Universitas Gajah Mada.

Munib, Achmad. (2004). Pengantar ilmu pendidikan. Semarang: UPT MKK UNNES

Pusat Kurikulum (2001). Kurikulum Berbasis Komperensi, Mata Pelajaran IPS Sekolah Dasar. Jakarta: Depdiknas.

Rahmatullah. (2018). Pembelajaran ekonomi berjatidiri bangsa. Jurnal Ekonomi dan Pendidikan, 1, 10-16. https://doi.org/10.26858/jekpend.v1i1.5055

Siraj-Blatchford, I. (2004). Educational disadvantage in the early years: How do we overcome it? Some lessons from research. European Early Childhood Education Research Journal, 12(2), $5-20$.

Sunanik, S. (2016). Menumbuhkan Ekonomi Kreatif Anak Usia Dini Melalui Pendidikan Keluarga. Jurnal Pendidikan Ekonomi (Jupeko), 1(1).

Undang-Undang Nomor 20 Tahun 2003 tentang Sistem Pendidikan Nasional Bab I Pasal 1 Ayat 14

Wibowo, A. (2012). Pendidikan Karakter Anak Usia Dini. Yogyakarta: Pustaka Pelajar.

Wibowo, A. (2012). Pendidikan karakter: Strategi membangun karakter bangsa berperadaban. Yogyakarta: Pustaka Pelajar.

Winder, C., \& Corter, C. (2016). The influence of prior experiences on early childhood education students' anticipated work with families. Teaching and Teacher Education, 55, 133-142. doi:10.1016/j.tate.2016.01.005. 